\title{
Thermal insulation in malnourished Jamaican children
}

\author{
O. G. BROOKE \\ with the assistance of Yvette March \\ From the Tropical Metabolism Research Unit, University of the West Indies, Kingston, Jamaica
}

\begin{abstract}
Brooke, O. G. (1973). Archives of Disease in Childhood, 48, 901. Thermal insulation in malnourished Jamaican children. The mean summed skinfold at 6 sites in 20 malnourished Jamaican children was $24.5 \mathrm{~mm}$ on admission to hospital and $49.8 \mathrm{~mm}$ on discharge. Marasmic children initially had thinner skinfolds than children with oedematous malnutrition, and they had a highly significant reduction in total specific thermal insulation. Children with oedema had no such reduction in insulation. During their first week in hospital there was a significant positive correlation between nocturnal mean rectal temperature in the malnourished children and their skinfold thickness and specific thermal insulation. Similar correlations for daytime rectal temperature were not statistically significant. We conclude that loss of thermal insulation may be of importance in the genesis of hypothermia in the sleeping malnourished child, whose posture and inactivity favour a negative heat balance.
\end{abstract}

Malnourished children with the greatest weight deficit are the most likely to become hypothermic (Brenton, Brown, and Wharton, 1967; Brooke, 1972a). Loss of subcutaneous fat is a prominent feature of infantile marasmus, so the resulting decrease in thermal insulation could be a factor contributing to the fall in body temperature. Insulation of the body core depends not only on the thermal conductivity of the tissues forming the shell, but also on the blood flow through them. The reduction in skin blood flow in malnourished children (Williams, 1955; Brooke, Harris, and Salvosa, 1973) might be expected to compensate to some extent for the loss of subcutaneous fat. We have carried out a number of studies to find out whether this is so.

\section{Patients and methods}

Twenty-six malnourished Jamaican children, 15 females and 11 males, were studied on admission to the Tropical Metabolism Research Unit, and at intervals during their recovery. Their mean age was 13.2 months (range 6-24). On admission they were, on average, $51 \%$ of their expected weight for age and $73 \%$ of their expected weight for height (Boston standards, Nelson, 1969). 11 had oedema. On the basis of the classification of the Wellcome Trust Working Party on malnutrition (Lancet, 1970), 15 had marasmus, 5 had kwashiorkor, and 6 had marasmic-kwashiorkor.

Skinfold thickness. Skinfolds were measured (Jelliffe, 1966) in 20 of the children throughout their stay

Received 17 May 1973. in hospital, using a Harpenden 'John Bull' caliper with jaws operating at $970 \mathrm{~g}$ pressure. Measurements were made in triplicate at the following sites: left triceps, left biceps, left subscapular, left subcostal, left iliac crest, and immediately below and to the left of the umbilicus. It was necessary to keep the caliper in place for several seconds in children with oedema to allow for the extrusion of excess water from the skinfold.

Overall specific thermal insulation. Specific insulation (I) per unit surface area was derived from the formula

$$
I=\frac{A\left(T_{R}-T_{E}\right)}{H_{C R}}(\text { Hey, Katz, and O'Connell, 1970), }
$$

where $A$ is the surface of the child in $\mathrm{m}^{2}, T_{R}$ is rectal temperature and $T_{E}$ environmental temperature in ${ }^{\circ} \mathrm{C}$, and $\mathrm{H}_{\mathrm{CR}}$ total heat lost from the body by convection and radiation in Joules/sec. The latter is given by the formula

$$
\mathrm{H}_{\mathrm{CR}}=\mathrm{M}-\mathrm{S}-\mathrm{H}_{\mathrm{E}}-\mathrm{H}_{\mathrm{K}} \text { (Hey et al., 1970), }
$$

where $M$ is the heat of metabolism, $S$ is heat storage, $H_{E}$ is evaporative heat loss, and $H_{K}$ is conductive heat loss. These various factors were determined as follows.

Surface area. This was derived from the formula

$\mathrm{A}\left(\mathrm{cm}^{2}\right)=$ weight $^{0.425} \times$ height $^{0.725} \times 71 \cdot 84$ (Du Bois, 1927).

Weight was measured on a beam balance to $\pm 5 \mathrm{~g}$ and height on a horizontal stadiometer to $0.25 \mathrm{~cm}$ by trained staff.

Rectal temperature. During the studies this was measured to $\pm 0.02{ }^{\circ} \mathrm{C}$ with a thermistor inserted about $6 \mathrm{~cm}$ into the rectum. Routine 4-hourly temperatures were taken by the nursing staff using low-reading clinical 
thermometers inserted for 2 minutes to a minimum depth of $2 \frac{1}{2} \mathrm{~cm}$.

Environmental temperature. All measurements were made in a perspex temperature-controlled metabolic chamber (Brooke, 1972b). Environmental temperature was calculated from the formula $T_{B}=0.4 T_{A}+0.6 T_{W}$ (Hey, 1969), where $T_{A}$ was the mean chamber air temperature (from the measured temperature of the air entering and leaving the chamber) and $T_{w}$ was the weighted mean of measurements of the surface temperature of the chamber inner wall made at 3 sites with thermistors. The mean difference between $\mathrm{T}_{\mathrm{W}}$ and $\mathrm{T}_{\mathrm{A}}$ was $0.55{ }^{\circ} \mathrm{C}(\mathrm{SD} 0.4)$.

Heat of metabolism. Metabolic rate was measured by indirect calorimetry using a recently calibrated Noyons diaferometer (Kipp and Zonen, Delft, Holland).

Heat storage. Any change in the heat content of the body during the period of measurement was determined from the change in mean body temperature, taking the specific body heat to be 0.83 and mean body temperature to be $0 \cdot 7 \mathrm{~T}_{\mathrm{R}}+0 \cdot 3 \mathrm{~T}_{S}$ (Burton and Edholm, 1955), where $T_{S}$ was the mean skin temperature. The latter was measured with 36 s.w.g. thermocouples at 4 sites (forehead, forearm, trunk, lateral thigh). The thermocouples were secured with adhesive tape, leaving the junctions bare but in contact with the skin. Mean skin temperature was derived from weightings based on the proportions of a 9-month-old child (Le Gros Clark and Medawar, 1945).

Evaporative heat loss. This was measured by wetand-dry bulb thermometry (Brooke, 1972b) at an air flow of $50 \mathrm{l} . / \mathrm{min}$.

Conductive heat loss. In all studies the babies lay on a

Experimental procedure. Measurements of total specific insulation were made within 48 hours of admission and again before discharge. All studies were done in the postabsorptive state and using sedation (paraldehyde $0.5 \mathrm{ml} / \mathrm{kg}$ body weight by enema). Since specific insulation changes with environmental were made at the same $T_{E}\left(30^{\circ} \mathrm{C}\right)$. The children were nylon mesh sling held 1 to $2 \mathrm{~cm}$ off the floor of the chamber, so conductive losses were negligible. temperature (Hey et al., 1970), all our measurements

naked except for a plastic urine collection bag, and when they were asleep they were placed on their backs on the nylon mesh sling, with forearms and hands resting across the lower abdomen, knees separated and slightly flexed, and feet together. Some care was taken with the positioning to eliminate posture as a variant in the measurements as far as was possible. A half-hour was allowed for equilibration in the chamber, in which the air speed did not exceed $10 \mathrm{~cm} / \mathrm{sec}$ and the water vapour pressure of the incoming air was regulated at about 10 $\mathrm{mmHg}$. After equilibration, measurements of body temperature and evaporative water loss were made at 5-minute intervals for a further 30 minutes, at the end of which metabolic rate was measured.

Units of measurement. Results of insulation measurements are expressed as

$$
\frac{{ }^{\circ} \mathrm{C} \mathrm{m}^{2} \mathrm{~s}}{\mathrm{~J}} \quad\left[\frac{1{ }^{\circ} \mathrm{C} \mathrm{m}^{2} \mathrm{~h}}{\mathrm{Kcal}}=\frac{0.86^{\circ} \mathrm{C} \mathrm{m}^{2} \mathrm{~s}}{\mathrm{~J}}\right] .
$$

\section{Results}

Skinfold thickness. Table I shows the mean skinfold thickness at the 6 different sites. Mean summed skinfold in all 20 children was lowest on the second day of hospital treatment at $24.5 \mathrm{~mm}$ (SD $8 \cdot 5)$, and highest in the week of discharge at $49 \cdot 8$ $\mathrm{mm}$ (SD 8.4). A rough estimate of the overall thickness of skin and subcutis can be obtained by dividing these figures by 6 , to give the average skinfold thickness, and again by 2 , to give the thickness of one layer of skin and subcutaneous fat. From this it can be seen that there was an overall increase in the thickness of the subcutaneous fat layer of about $2 \mathrm{~mm}$.

Lowest summed skinfold from 6 sites in 9 marasmic children was $20 \cdot 4 \mathrm{~mm}$ (SD $4 \cdot 0$ ), and in 5 children with kwashiorkor it was $30.3 \mathrm{~mm}$ (SD 9.4), a significant difference of $9.9 \mathrm{~mm}(\mathrm{t}=2 \cdot 4$, $\mathbf{P}<0 \cdot 05)$. 6 children with marasmic-kwashiorkor were intermediate with a value of $25 \cdot 7 \mathrm{~mm}$ (SD $9 \cdot 5)$. There was no significant difference between

TABLE I

\section{Mean skinfold thickness ( $\mathrm{mm}$ ) (and SD) at 6 measurement sites in malnourished and recovered children}

\begin{tabular}{|c|c|c|c|c|}
\hline \multirow{2}{*}{ Skinfold } & \multicolumn{3}{|c|}{ Malnourished } & \multirow{2}{*}{ Recovered (20) } \\
\hline & Marasmus (9) & Marasmic-kwashiorkor (6) & Kwashiorkor (5) & \\
\hline $\begin{array}{l}\text { Biceps } \\
\text { Triceps } \\
\text { Subscapular } \\
\text { Costal margin } \\
\text { Umbilicus } \\
\text { Iliac crest }\end{array}$ & $\begin{array}{l}3 \cdot 7( \pm 0 \cdot 7) \\
4 \cdot 7( \pm 1 \cdot 0) \\
3 \cdot 3( \pm 0 \cdot 6) \\
2 \cdot 6( \pm 0 \cdot 7) \\
3 \cdot 2( \pm 1 \cdot 1) \\
2 \cdot 9( \pm 0 \cdot 9)\end{array}$ & $\begin{array}{l}4 \cdot 6( \pm 1 \cdot 8) \\
6 \cdot 0( \pm 2 \cdot 6) \\
3 \cdot 6( \pm 1 \cdot 0) \\
3 \cdot 0( \pm 1 \cdot 2) \\
4 \cdot 5( \pm 1 \cdot 9) \\
4 \cdot 0( \pm 1 \cdot 6)\end{array}$ & $\begin{array}{l}5 \cdot 6( \pm 1 \cdot 7) \\
7 \cdot 1( \pm 2 \cdot 7) \\
4 \cdot 4( \pm 1 \cdot 4) \\
3 \cdot 4( \pm 1 \cdot 5) \\
5 \cdot 7( \pm 2 \cdot 7) \\
4 \cdot 1( \pm 1 \cdot 7)\end{array}$ & $\begin{array}{r}7 \cdot 7( \pm 1 \cdot 8) \\
11 \cdot 9( \pm 2 \cdot 9) \\
7 \cdot 7( \pm 1 \cdot 3) \\
6 \cdot 2( \pm 1 \cdot 6) \\
8 \cdot 7( \pm 1 \cdot 2) \\
7 \cdot 6( \pm 1 \cdot 8)\end{array}$ \\
\hline$\overline{\text { Summed skinfold }}$ & $20 \cdot 4$ & $25 \cdot 7$ & $30 \cdot 3$ & $49 \cdot 8$ \\
\hline
\end{tabular}


TABLE II

Total specific thermal insulation $\left({ }^{\circ} \mathrm{C} \mathrm{m}^{2} \mathrm{~s} / J\right)$ in 26 malnourished children before and after treatment

\begin{tabular}{|c|c|c|c|c|}
\hline & Malnourished & Recovered & $t$ & $\mathbf{P}$ \\
\hline $\begin{array}{l}\text { All (26) } \\
\text { Marasmus (15) } \\
\text { Oedematous (11) }\end{array}$ & $\begin{array}{l}0.190(0.076) \\
0.142(0.034) \\
0.255(0.068)\end{array}$ & $\begin{array}{l}0.194(0.043) \\
0.187(0.031) \\
0.204(0.054)\end{array}$ & $\begin{array}{l}\text { NS } \\
5 \cdot 1 \\
1 \cdot 9\end{array}$ & $\begin{array}{l}<0.001 \\
>0.05 \text { (NS) }\end{array}$ \\
\hline
\end{tabular}

Note: SD in parentheses. NS, not significant.

the skinfolds of oedematous and marasmic children after recovery.

Total specific thermal insulation. The results of these measurements are shown in Table II. The ' $\mathrm{t}$ ' tests were applied to paired comparison. There was no difference in the mean specific insulation for the whole group before and after treatment, but the marasmic children had a highly significant reduction in insulation of about $33 \%$. The mean for the oedematous children was higher on admission than it was after treatment, but the difference was not statistically significant.

Heat storage. Mean heat storage during 1 hour at $30^{\circ} \mathrm{C}$ was negative in the malnourished children $(-33.5 \mathrm{~J} /$ child per $\mathrm{min}$ ) and positive after recovery $(+109 \mathrm{~J} /$ child per $\mathrm{min})$. Marasmic children were in greater negative heat balance ( $-55 \mathrm{~J} /$ child per $\mathrm{min}$ ) than oedematous children $(-3 \cdot 4 \mathrm{~J} /$ child per min).

Relation between skinfold thickness, specific insulation, and rectal temperature. Since rectal temperature has been shown to be related to skinfold thickness in nude men during exposure to cold (Medical Nutrition Laboratory Report, 1953; Baker and Daniels, 1956), we examined the relation between total specific insulation, skinfold thickness, and mean rectal temperature in these children during their first week of hospital treatment. Rectal temperature measurements were taken from the routine 4-hourly temperature records. We felt that a significant relation between tissue insulation and rectal temperature would be most likely to occur at night when the children were asleep and inactive, so we analysed separately the day (10 a.m., 2 p.m., 6 p.m.) and night ( 10 p.m., 2 a.m., 6 a.m.) periods. Mean rectal temperature during both these periods in the first 7 days of hospital treatment (21 measurements) was correlated separately with mean skinfold thickness during the same week and with the initial measurement of total specific insulation. The results are shown in Table III. Correlations in the daytime, though positive, were poor. However, there was a highly significant positive correlation between nocturnal rectal temperature and both skinfold thickness and specific insulation, as shown in the Fig.

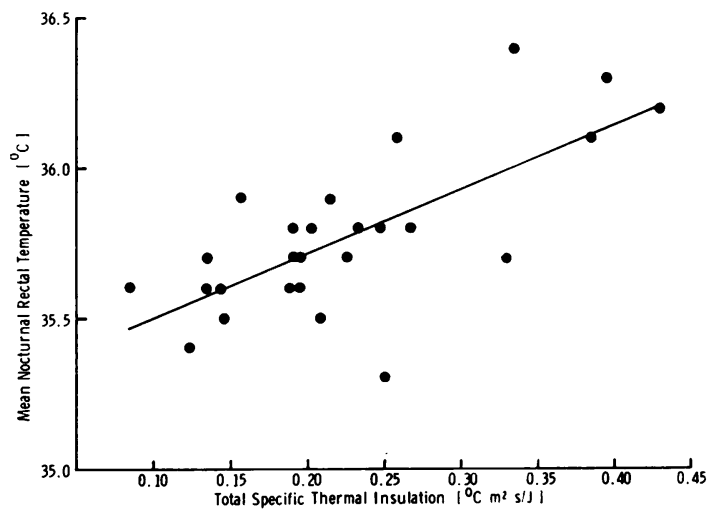

Fig.-Relation between mean nocturnal rectal temperature during first week of hospital treatment and total specific thermal insulation in 26 malnourished children.

TABLE III

Relation between mean rectal temperature and skinfold thickness (20 children) and total specific insulation (26 children) in first week of hospital treatment for malnutrition

\begin{tabular}{|c|c|c|c|c|c|c|}
\hline & \multicolumn{3}{|c|}{ Daytime } & \multicolumn{3}{|c|}{ Night time } \\
\hline & $\mathbf{r}$ & $\mathbf{t}$ & $\mathbf{P}$ & $\mathbf{r}$ & $\mathbf{t}$ & $\mathbf{P}$ \\
\hline $\begin{array}{l}T_{\overline{\mathrm{B}}} \text { vs skinfold thickness } \\
\mathrm{T}_{\overline{\mathrm{R}}} \text { vs total specific insulation }\end{array}$ & $\begin{array}{l}+0.29 \\
+0.31\end{array}$ & $\begin{array}{l}1 \cdot 3 \\
1 \cdot 6\end{array}$ & $\begin{array}{l}>0.05 \text { (NS) } \\
>0.05 \text { (NS) }\end{array}$ & $\begin{array}{l}+0 \cdot 68 \\
+0 \cdot 72\end{array}$ & $\begin{array}{l}3 \cdot 9 \\
5 \cdot 1\end{array}$ & $\begin{array}{r}0.001 \\
<0.001\end{array}$ \\
\hline
\end{tabular}

NS, not significant. 


\section{Discussion}

Although adipose tissue is principally a calorie store, its subcutaneous distribution enables it to function as an insulating jacket as well. Fat has much lower thermal conductivity than muscle (Hatfield and Pugh, 1951), and so is well suited for this purpose. Loss of subcutaneous fat is one of the most obvious clinical features of nutritional marasmus, and since marasmic children also have a lowered rate of metabolic heat production (Varga, 1959; Montgomery, 1962; Brooke and Cocks, 1973), the loss of thermal insulation accompanying depletion of the fat stores could be an important factor in the aetiology of hypothermia. It is suggestive that in Jamaica (Brooke, 1972a) hypothermia is uncommon in children with kwashiorkor in whom, as we have shown in this study, subcutaneous fat is relatively well maintained and overall specific insulation is increased. In contrast, the marasmic children, who often become hypothermic, had thinner skinfolds and reduced thermal insulation. Similarly, in Uganda (Brenton et al., 1967) malnourished children with substantial triceps skinfolds did not become hypothermic, while those with skinfold less than $7 \mathrm{~mm}$ thick often did.

The large difference in specific insulation between children with oedematous malnutrition and those with marasmus cannot be accounted for entirely by differences in skinfold thickness, since some children with marasmic-kwashiorkor had thin skinfolds but high insulation. In normal circumstances peripheral circulation is the other important variable determining the degree of insulation. Reduced peripheral blood flow and circulatory insufficiency occur in both marasmic and oedematous forms of malnutrition (Alleyne, 1966; Brooke et al., 1973), but we do not know of any studies that have shown a greater degree of circulatory impairment in the latter. This possibility would be worth investigating. However, the unperfused and relatively inert oedema fluid, though of higher thermal conductivity than fat, probably has significant insulating properties in these children, many of whom look frankly marasmic when the oedema is lost, and sometimes have an accompanying fall in rectal temperature (Brooke, 1972a).

Malnourished children are at greatest risk of hypothermia at night (Staff, 1968) when they are sleeping and inactive, often unfed, separated from maternal warmth, at the lowest point in their circadian rhythm, and exposed to lower ambient temperatures than in the day. The data reported here show that the children with the thinnest skinfolds and lowest specific insulation had the lowest rectal temperatures at night and so were more vulnerable than the less emaciated children. During the day the relation between specific insulation and rectal temperature became insignificant. The reason for this difference is probably concerned with posture and activity. The seriously malnourished child is hypotonic and tends to lie spread-eagled when asleep, exposing a large surface area to radiant and convective heat loss. When awake, though much less active than normal, he can maintain a more suitable posture for minimizing heat loss and often huddles in a kneeling position. The alarming fall in body temperature which may accompany short periods of daytime sleep in malnourished children (Brooke, 1972c) can probably also be explained on the basis of unfavourable posture, loss of tissue insulation, and reduced metabolic heat production.

Malnourished children have an absent or inadequate metabolic response to cold (KerpelFronius, Varga, and Kun, 1954; Brooke et al., 1973) and so are very much at the mercy of their environment. Even at $30^{\circ} \mathrm{C}$ and with little air movement, most of the marasmic children whom we studied were in negative heat balance, in contrast to the situation after recovery when there was no tendency for body temperature to fall under these conditions. Hence the neutral thermal environment for malnourished children is higher than for normal children of the same age, and great care must be taken to ensure that they have adequately warm coverings at night and when asleep in the daytime.

We are indebted to Professor O. G. Edholm for his advice on the preparation of the manuscript.

\section{REFERENCES}

Alleyne, G. A. O. (1966). Cardiac function in severely malnourished Jamaican children. Clinical Science, 30, 553.

Baker, P. T., and Daniels, F., Jr. (1956). Relationship between skinfold thickness and body cooling for two hours at $15^{\circ} \mathrm{C}$. Fournal of Applied Physiology, 8, 409.

Brenton, D. P., Brown, R. E., and Wharton, B. A. (1967). Hypothermia in kwashiorkor. Lancet, $1,410$.

Brooke, O. G. (1972a). Hypothermia in malnourished Jamaican children. Archives of Disease in Childhood, 47, 525.

Brooke, O. G. (1972b). A simple metabolism chamber allowing determinations of evaporative water loss in large babies. West Indian Medical fournal, 21, 202.

Brooke, O. G. (1972c). Influence of malnutrition on the body temperature of children. British Medical fournal, $1,331$.

Brooke, O. G., and Cocks, T. (1973). The metabolic rate of malnourished children. Fournal of Physiology, 231, 18P.

Brooke, O. G., Harris, M., and Salvosa, C. (1973). The response of malnourished children to cold. Fournal of Physiology, 233, 75.

Burton, A. C., and Edholm, O. G. (1955). Man in a Cold Environment, p. 41. Arnold, London.

Du Bois, E. F. (1927). Basal Metabolism in Health and Disease, 2nd ed., p. 124. Lea and Febiger, Philadelphia.

Hatfield, H. S., and Pugh, L. G. C. (1951). Thermal conductivity of human fat and muscle. Nature, 168, 918. 
Hey, E. N. (1969). The relation between environmental temperature and oxygen consumption in the newborn baby. Fournal of Physiology, 200, 589.

Hey, E. N., Katz, G., and O'Connell, B. (1970). The total thermal insulation of the newborn baby. Fournal of Physiology, 207, 683.

Jelliffe, D. B. (1966). The Assessment of the Nutritional Status of the Community, p. 72. W.H.O., Geneva.

Kerpel-Fronius, E., Varga, F., and Kun, K. (1954). Pathogenese der Dekomposition. II. Die Bedeutung der Anoxie, Hypothermie und Hypoglykaemie im Endzustand der Săuglingsatrophie. Annales Paediatrici, 183, 1.

Lancet (1970). Annotation. Classification of infantile malnutrition, $2,302$.

Le Gros Clark, W. E., and Medawar, P. B. (1945). (Editors.) Essays on Growth and Form. Clarendon Press, Oxford.

Medical Nutrition Laboratory Report (1953). No. 115, 15 September 1953 (United States Army), Washington, D.C.
Montgomery. R. D. (1962). Changes in the basal metabolic rate ot the malnourished infant, and their relation to body composition. Fournal of Clinical Investigation, 41, 1653.

Nelson, W. E. (1969). Textbook of Pediatrics, 9th ed., p. 40. Ed. by W. E. Nelson, V. C. Vaughan, and R. J. McKay. Saunders, Philadelphia and London.

Staff, T.H.E. (1968). Treatment of severe kwashiorkor and marasmus in hospital. East African Medical fournal, 45, 399.

Varga, F. (1959). The respective effects of starvation and changed body composition on energy metabolism in malnourished infants. Pediatrics, 23, 1085.

Williams, C. D. (1955). Protein Malnutrition: Proceedings of a Conference in Famaica, 1953, p. 56. Ed. by J. C. Waterlow. Printed at University Press, Cambridge, for the Food and Agriculture Organization.

Correspondence to Dr. O. G. Brooke, Department of Paediatrics, St. Mary's Hospital, London W2. 